\title{
Glottic Cancer pT4 TNM Finding v8
}

National Cancer Institute

\section{Source}

National Cancer Institute. Glottic Cancer pT 4 TNM Finding v8. NCI Thesaurus. Code C133116.

Glottic cancer with moderately advanced or very advanced disease. (from AJCC 8th Ed.) 